\title{
DETERMINAN KINERJA MANAJERIAL PADA ORGANISASI PERANGKAT DAERAH (OPD) KABUPATEN KUDUS
}

\author{
Nanik Ermawati \\ Program Studi Akuntansi Fakultas Ekonomi \& Bisnis Universitas Muria Kudus \\ nanik.ermawati@umk.ac.id \\ Nurul Rizka Arumsari \\ Program Studi Akuntansi Fakultas Ekonomi \& Bisnis Universitas Muria Kudus \\ nurul.rizka@umk.ac.id
}

\begin{abstract}
Abstrak: Determinan Kinerja Manajerial Pada Organisasi Perangkat Daerah (OPD) Kabupaten Kudus). Penyusunan anggaran pada Organisasi Perangkat Daerah Kabupaten Kudus menerapkan model partisipasi anggaran yaitu melibatkan pegawai OPD dari kepala OPD sampai dengan staff. Dengan adanya keterlibatan pegawai OPD dalam menyusun anggaran ini dapat memberikan peningkatan kinerja manajerial pegawai OPD dalam bekerja. Namun ada beberapa faktor lain yang dapat meningkatkan kinerja tersebut antara lain sistem perencanaan anggaran, skedul penyusunan anggaran, kejelasan sasaran anggaran, kualitas sumber daya manusia. Penelitian ini dilakukan dengan metode kuesioner terhadap pegawai OPD yang terdiri dari kepala organisasi perangkat daerah, kepala bidang, kepala seksi dan staff. Alat uji yang digunakan dalam penelitian ini adalah Moderate Regression Analysis (MRA). Hasil pengujian menunjukkan bahwa partisipasi penyusunan anggaran tidak berpengaruh terhadap kinerja manajerial, Sistem perencanaan anggaran tidak berpengaruh terhadap kinerja manajerial, Skedul penyusunan anggaran tidak berpengaruh terhadap kinerja manajerial, Kejelasan anggaran berpengaruh positif terhadap kinerja manajerial, Kualitas sumber daya manusia tidak mampu memperkuat pengaruh sistem perencanaan anggaran terhadap kinerja manajerial, Kualitas sumber daya manusia tidak mampu memperkuat pengaruh partisipasi penyusunan anggaran terhadap kinerja manajerial, Kualitas sumber daya manusia tidak mampu memperkuat pengaruh skedul penyusunan anggaran terhadap kinerja manajerial, Kualitas sumber daya manusia mampu memperkuat pengaruh kejelasan anggaran terhadap kinerja manajerial.
\end{abstract}

Kata kunci: partisipasi anggaran, kinerja manajerial, kualitas sumber daya manusia

\begin{abstract}
Determinants Of Managerial Performance In Regional Development Organizations (OPD) Kudus Regency). Budgeting in the Kudus Regency Regional Development Organization implements a budget participation model that involves OPD employees from the head of the OPD to the staff. With the involvement of OPD employees in preparing this budget can provide an increase in the managerial performance of $O P D$ employees at work. However, there are several other factors that can improve performance, including budget planning systems, budget planning schedules, clarity of budget targets, quality of human resources. This research was conducted by a questionnaire method of OPD employees consisting of heads of regional apparatus organizations, heads of departments, section heads and staff. The test equipment used in this study was Moderate Regression Analysis (MRA). The test results show that budgetary participation has no effect on managerial performance, the budget planning system has no effect on managerial performance, budget planning schedules do not affect managerial performance, budget clarity has a positive effect on managerial performance, the quality of human resources is unable to strengthen the influence of the budget planning system on managerial performance, the quality of human resources cannot strengthen the influence of budgetary participation on managerial performance, the quality of human resources cannot strengthen the influence of budget
\end{abstract}


planning schedules on managerial performance, the quality of human resources is able to strengthen the influence of budget clarity on managerial performance.

Keywords: budget participation, managerial performance, quality of human resources

\section{PENDAHULUAN}

Organisasi Perangkat Daerah (OPD) merupakan lembaga pemerintahan yang menyelenggarakan pemerintah di daerah. Dalam menyelenggarakan pemerintahan tersebut tentunya OPD memiliki standar yang harus dipenuhi demi kesejahteraan masyarakat. Untuk memperoleh kesejahteraan masyarakat tersebut OPD memiliki ukuran kinerja bagi organisasinya. Tingkat kinerja yang dimiliki oleh OPD sangat penting bagi masyarakat. Kinerja yang dimaksud adalah kinerja manajerial. Dimana kinerja manajerial adalah seberapa jauh prestasi yang dimiliki organisasi yang dikaitkan dengan visi misi organisasi (Ermawati, 2017). Dengan kata lain prestasi organisasi dilihat dari seberapa jauh prestasi yang sudah diperoleh organisasi tersebut.

Berdasarkan teori agensi Bergman \& Lane (1990) yang menghubungkan antara agen yaitu pemerintah daerah dengan principal yaitu masyarakat. Hubungan ini merupakan hubungan kepercayaan dimana masyarakat memberi wewenang penuh kepada pemerintah daerah untuk mengelola pemerintahan sehingga pemerintah daerah harus mempertanggungjawabkan pekerjaannya. Dalam mempertanggungjawabkan pekerjaannya ini pemerintah daerah harus memiliki kinerja manajerial yang bagus. Jika kinerja manajerial jelek bagaimana pemerintah daerah dapat mempertanggungjawabkan pekerjaannya.

Sangat pentingnya kinerja manajerial bagi OPD ini, ada beberapa faktor yang dapat mempengaruhinya. Salah satu faktor yang dapat mempengaruhi kinerja manajerial adalah partisipasi anggaran. Partisipasi merupakan tingkat keterlibatan semua pegawai di semua level untuk turut serta menentukan jumlah anggaran dibutuhkan organisasi. Ketika pegawai bawahan dan pegawai atasan (Staff, Kabid, Kabag, Ketua OPD) bersama-sama menentukan jumlah anggaran akan menghasilkan anggaran yang efektif (Ermawati, 2017). Hal ini dikarenakan pihak staff akan lebih paham kebutuhan yang ada di lapangan karena setiap hari staff sebagai pelaksana dalam OPD. Dengan adanya keterlibatan tersebut diharapkan akan memberikan dampak yang baik bagi organisasi (Fitriana et al., 2018). Hal ini sejalan dengan penelitian yang telah dilakukan oleh (Hidayat, 2014), (Gunawan, 2017), (Oyewo \& Adyeye, 2018), (Syafrial, 2009). Namun penelitian ini tidak konsisten 
dengan hasil penelitian dari Ermawati (2017), yang menunjukkan bahwa partisipasi anggaran tidak mampu mempengaruhi kinerja manajerial.

Selain partisipasi anggaran, faktor lainnya yang berpengaruh terhadap kinerja manajerial adalah sistem perencanaan anggaran. Sistem perencanaan anggaran yang baik jika anggaran yang telah disusun oleh organisasi sesuai dengan target organisasi sehingga sesuai dengan kebutuhan organisasi (Hamid, 2011). Begitu juga menurut Hidayat (2014) ketika anggaran yang telah disusun ini dapat dilaksanakan sesuai dengan anggaran yang telah ditetapkan hal ini menunjukkan prestasi yang bagus bagi organisasi. Dengan kata lain ketika anggaran disusun dengan sistem perencanaan yang baik akan menghasilkan kinerja manajerial yang bagus bagi organisasi. Hal ini mendukung penelitian yang telah dilakukan oleh (Hidayat, 2014) dan (Hamid, 2011).

Faktor selanjutnya yang mempengaruhi kinerja manajerial adalah skedul penyusunan anggaran. Dalam menyusun anggaran alangkahbaiknya mengacu pada skedul yang telah ditetapkan oleh pemerintah. Semakin tepat pelaksanaan penyusunan anggaran ini sesuai dengan kalender penyusunan anggaran, maka kinerja manajerial OPD akan meningkat. Hal ini menunjukkan bahwa anggaran yang tepat waktu akan membantu jalannya perekonomian daerah (Hidayat, 2014). Hal ini sejalan dengan hasil penelitian dari Hidayat (2014), dimana semakin tepat waktu dalam menyusun anggaran akan menghasilkan kinerja manajerial yang baik pula.

Selanjutnya kinerja manajerial juga dapat dipengaruhi melalui kejelasan sasaran anggaran. OPD yang mampu menyusun anggaran sesuai dengan target dan sasaran anggaran yang jelas akan mampu mempengaruhi kinerja manajerial. Ketika OPD mampu menyusun kebutuhan OPD sesuai dengan kondisi yang sebenarnya maka kebutuhan OPD akan terpenuhi. Hal inilah menyebabkan kinerja manajerial meningkat. Hasil penelitian ini sejalan dengan penelitian yang telah dilakukan oleh Hidayat (2014), Syafrial (2009), Gunawan (2017) yang menunjukkan bahwa semakin tinggi tingkat kejelasan sasaran anggaran OPD maka akan meningkat juga kinerja manajerial OPD tersebut. Namun berbeda dengan penelitian yang telah dilakukan oleh Fitriana et al., (2018), dimana kejelasan sasaran anggaran tidak mampu mempengaruhi kinerja manajerial.

Penelitian ini merupakan penelitian lanjutan yang pernah dilakukan oleh Hidayat (2014). Namun penelitian ini berbeda dengan Hidayat (2014). Perbedaan penelitian sekarang dengan penelitian terdahulu adalah 
dengan menambahkan variabel moderating kualitas sumber daya manusia. Penambahan variabel ini merupakan saran dari penelitian Hidayat (2014). Selain itu kualitas sumber daya manusia merupakan faktor penting yang dibutuhkan organisasi untuk menentukan kinerja manajerial organisasi (Gunawan, 2017). Selain penambahan variabel, perbedaannya yang kedua adalah dari sisi objek yang digunakan. Objek penelitian yang digunakan dalam penelitian ini adalah OPD di Kabupaten Kudus.

Objek penelitian ini di pilih di Kabupaten Kudus, karena ada masalah dalam proses penyusunan anggaran pada tahun 2018. Berdasarkan fraksi DPRD Anggaran Pendapatan dan Belanja Daerah (APBD) pada Kabupaten Kudus di tahun 2018 mengalami penurunan dibandingkan dengan anggaran tahun 2017 (N.A, 2018). Pada tahun 2017, APBD Kabupaten Kudus sebesar 1,82 trilyun, sedangkan APBD pada tahun 2018 sebesar 1,66 trilyun. Hal ini menunjukkan bahwa APBD pada tahun 2018 menurun sebesar 0,16 trilyun. Seharusnya APBD itu dari tahun ke tahun sebaiknya meningkat. Namun berbeda dengan Kabupaten Kudus ini, dimana tahun terakhir dalam penyusunan APBD ini malah menurun.

Tujuan dari penelitian ini adalah: 1). Untuk menganalisis partisipasi anggaran berpengaruh terhadap kinerja manajerial pada OPD di Kabupaten Kudus 2). Untuk menganalisis sistem perencanaan anggaran terhadap kinerja manajerial pada OPD Kabupaten Kudus 3). Untuk menganalisis skedul penyusunan anggaran terhadap kinerja manajerial pada OPD Kabupaten Kudus 4). Untuk menganalisis kejelasan sasaran anggaran terhadap kinerja manajerial pada OPD Kabupaten Kudus 5). Untuk menganalisis kualitas sumber daya manusia dalam memoderasi pengaruh antara partisipasi anggaran terhadap kinerja manajerial pada OPD Kabupaten Kudus 6).Untuk menganalisis kualitas sumber daya manusia dalam memoderasi pengaruh antara sistem perencanaan anggaran terhadap kinerja manajerial pada OPD Kabupaten Kudus 7). Untuk menganalisis kualitas sumber daya manusia dalam memoderasi pengaruh antara skedul penyusunan anggaran terhadap kinerja manajerial pada OPD Kabupaten Kudus 8).Untuk menganalisis kualitas sumber daya manusia dalam memoderasi pengaruh antara kejelasan sasaran anggaran terhadap kinerja manajerial pada OPD Kabupaten Kudus.

Berdasarkan riset gap dan fenomena yang telah terjadi, maka peneliti tertarik untuk meneliti lebih lanjut terkait dengan kinerja manajerial dengan judul penelitian sebagai berikut: "Determinan Kinerja Manajerial Pada Organisasi Perangkat Daerah (OPD) Kabupaten Kudus). 


\section{KAJIAN LITERATUR}

\section{a. Partisipasi Anggaran dan Kinerja Manajerial}

Partisipasi anggaran diartikan sebagai proses keikutsertaan manajer pusat pertanggungjawaban dalam menyusun anggaran dan mempengaruhi target anggaran sebagai bagian utama atas tanggung jawabnya (Matondang et al., 2015). Partisipasi anggaran umumnya dinilai sebagai pendekatan manajerial yang dapat meningkatkan kinerja organisasi (Matondang et al., 2015). Ketika suatu organisasi dalam penyusunan anggaran melibatkan partisipasi dari semua manajer pusat pertanggungjawaban maka akan menciptakan rasa memiliki terhadap suatu organisasi sehingga kinerjanya semakin meningkat. Selain itu, adanya partisipasi memberikan kesempatan bagi manajer pusat pertanggungjawaban untuk ikut andil dalam pengambilan keputusan melalui penyusunan anggaran. Hal ini akan meningkatkan produktivitas dan rasa puas akan pekerjaannya sehingga memungkinkan peningkatan kinerja. Hasil penelitian Gunawan (2017), Syafrial (2009), Oyewo \& Adyeye (2018) menemukan bukti bahwa partisipasi anggaran berpengaruh terhadap kinerja manajerial.
Oleh karena itu, dirumuskan hipotesis penelitian sebagai berikut:

H1: Partisipasi penyusunan anggaran berpengaruh positif terhadap kinerja manajerial.

\section{b. Sistem Perencanaan Anggaran dan Kinerja Manajerial}

Anggaran memiliki peran penting dalam organisasi sektor publik. Hidayat (2014) menyebutkan anggaran merupakan suatu rencana keuangan periodik yang disusun berdasarkan program yang disahkan, dimana perencanaan merupakan tindakan yang dibuat berdasarkan fakta dan asumsi mengenai gambaran kegiatan yang akan dilakukan pada waktu yang akan datang dalam mencapai tujuan yang diinginkan. Halim \& Kusufi (2014) mengemukakan bahwa anggaran adalah dokumen yang berisi estimasi kinerja, baik berupa penerimaan dan pengeluaran, yang daisajikan dalam ukuran moneter yanga kan dicapai pada periode waktu tertentu dan menyertakan data masa lalu sebagai bentuk pengendalian dan penilaian kinerja.

Sementara itu, sistem penganggaran merupakan instrumen dan mekanisme birokrasi pada suatu organisasi yang berfungsi sebagai alat untuk mengalokasikan sumber daya dalam bentuk barang dan jasa yang ada ke dalam organisasi (Halim \& Kusufi, 2014). 
Penganggaran merupakan proses penerjemahan rencana aktivitas ke dalam rencana keuangan (Hidayat, 2014). Terdapat beberapa atribut dalam penganggaran diantaranya sistem perencanaan anggaran, partisipasi penyusunan anggaran, skedul penyusunan anggaran, dan kejelasan anggaran. Sistem perencanaan memberikan informasi yang menyeluruh terkait tujuan yang akan dicapai. Untuk mencapai tujuan organisasi, manajemen harus membuat langkah-langkah proaktif dalam melakukan perencanaan yang komprehensif agar sasaran dan tujuan yang telah ditetapkan dapat dicapai (Dewi et al., 2017). Anggaran sebagai alat perencanaan digunakan untuk merencanakan berbagai program dan kegiatan untuk mencapai tujuan organisasi berserta alternatif pembiayaannya sehingga dapat digunakan sebagai indikator kinerja. Ketika sistem perencanaan anggaran dilakukan secara menyeluruh, transparan dan jelas maka akan memberikan informasi yang akurat terkait dengan tujuan yang ingin dicapai oleh organisasi sehingga kinerja manajerial dapat meningkat. Hasil penelitian Hidayat (2014), Hamid (2011), Haykal (2007) menunjukkan bahwa sistem perencanaan anggaran berpengaruh terhadap kinerja manajerial.
Berdasarkan kerangka konseptual tersebut maka dapat dirumuskan hipotesis penelitian sebagai berikut:

$\mathrm{H} 2$ : Sistem perencanaan anggaran berpengaruh positif terhadap kinerja manajerial.

\section{c. Skedul Penyusunan Anggaran dan Kinerja Manajerial}

Ketepatan skedul penyusunan anggaran merupakan tingkat kesesuaian waktu penyusunan anggaran yang telah dilaksanakan dibandingkan dengan kalender penyusunan anggaran yang telah ditetapkan (Hidayat, 2014). Informasi akan lebih berguna jika informasi yang dihasilkan tepat waktu. Dalam hal ini, program-program yang dicanangkan serta alternatif pembiayaannya dilakukan secara optimal dalam rangka mencapai tujuan organisasi. Hasil penelitian Syafrial (2009), Fauziah et al., (2017), Hidayat (2015) menunjukkan bahwa skedul penyusunan anggaran berpengaruh terhadap kinerja manajerial.

Oleh karena itu, jika skedul penyusunan anggaran dilakukan secara tepat maka akan mendorong peningkatan kinerja manajerial sehingga dapat dirumuskan hipotesis penelitian sebagai berikut:

H3: Skedul penyusunan anggaran berpengaruh positif terhadap kinerja manajerial. 
d. Kejelasan Sasaran Anggaran dan Kinerja Manajerial

Menurut Zein et al., (2016), kejelasan anggaran merupakan sejauh mana tujuan anggaran ditetapkan secara jelas dan spesifik dengan tujuan agar anggaran tersebut dapat dimengerti oleh orang yang bertanggung jawab atas pencapaian sasaran anggaran. Hasil penelitian Hidayat (2015), Gunawan (2017), Syafrial (2009), Putra (2013) menunjukkan bahwa kejelasan sasaran anggaran berpengaruh positif terhadap kinerja manajerial.

Ketika anggaran disusun secara jelas maka akan memudahkan aparat pemerintahan untuk melaksanakan targettarget yang ingin dicapai melalui berbagai program yang telah direncanakan. Dengan informasi anggaran tersebut maka aparat pemerintahan dapat memprediksi masa depan dan menjalankan program dengan optimal sehingga tercipta peningkatan kinerja sehingga dapat dirumuskan hipotesis sebagai berikut:

H4: Kejelasan anggaran berpengaruh positif terhadap kinerja manajerial.

e. Kualitas Sumber Daya Manusia, Partisipasi Anggaran, Sistem Perencanaan Anggaran, Skedul Penyusunan Anggaran, Kejelasan Sasaran Anggaran, Kinerja Manajerial Sumber daya manusia merupakan komponen paling penting dalam melakasanakan kebijakan. Dalam hal ini, sumber daya manusia menjadi pilar penyangga utama sekaligus penggerak roda organisasi dalam usaha mewujudkan visi dan misi serta tujuan dari organisasi. Dengan demikian, sumber daya manusia yang berkualitas berperan penting dalam pencapaian tujuan organisasi. Tanpa adanya sumber daya manusia yang berkualitas, sebaik apapun sistem yang diterapkan oleh organisasi tidak akan mampu memberikan kinerja yang optimal. Oleh karena itu, kualitas sumber daya manusia yang tercermin dari keterampilan, sikap, dan pengetahuan dapat mendorong peningkatan kinerja manajerial. Ketika sistem perencanaan anggaran dilakukan secara menyeluruh dan jelas, adanya partisipasi penyusunan anggaran, skedul penyusunan anggaran dilakukan secara tepat, dan adanya kejelasan anggaran kemudian didukung dengan kualitas sumber daya manusia yang tinggi maka akan tercipta kinerja manajerial yang lebih baik dibandingkan ketika kualitas sumber daya manusianya rendah. Berdasarkan kerangka konseptual tersebut maka dirumuskan hipotesis penelitian sebagai berikut:

H5: Kualitas sumber daya manusia memperkuat pengaruh sistem perencanaan anggaran terhadap kinerja manajerial. 
H6: Kualitas sumber daya manusia memperkuat pengaruh partisipasi penyusunan anggaran terhadap kinerja manajerial.

H7: Kualitas sumber daya manusia memperkuat pengaruh skedul penyusunan anggaran terhadap kinerja manajerial.

H8: Kualitas sumber daya manusia memperkuat pengaruh kejelasan anggaran terhadap kinerja manajerial.

Berdasarkan hipotesis yang diajukan dalam penelitian di atas, maka kerangka penelitian dalam penelitian ini sebagai berikut:

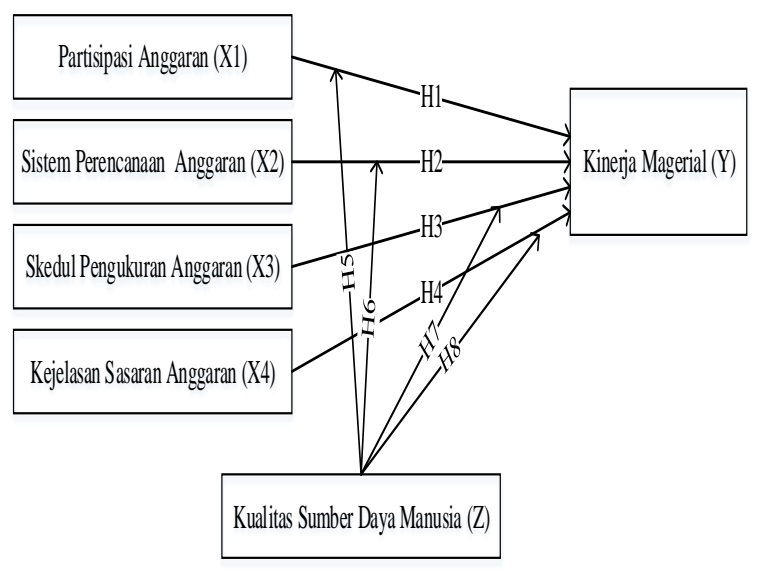

Gambar 1: Kerangka Konseptual

\section{METODE PENELITIAN}

\section{Jenis Penelitian}

Jenis penelitian yang digunakan dalam penelitian ini adalah jenis penelitian kuantitatif. Jenis penelitian ini merupakan jenis penelitian yang menggunakan angka dalam pengumpulan data dan digunakan untuk meneliti populasi atau sampel tertentu (Sugiyono, 2012).

\section{Tempat dan Waktu Penelitian}

Tempat pelaksanaan penelitian ini di OPD Kabupaten Kudus yang terdiri dari 43 OPD. Waktu pelaksanaan penelitian ini mulai tanggal 18 Januari 2019 sampai dengan 18 Februari 2019.

\section{Subjek Penelitian}

Populasi dalam penelitian ini adalah seluruh pegawai yang bekerja pada Organisasi Perangkat Daerah (OPD) Kabupaten Kudus yang berjumlah 43 OPD. Teknik pengambilan sampel yang digunakan dalam penelitian ini menggunakan metode non probability sampling dengan jenis sample random sampling. Populasi yang digunakan dalam penelitian ini adalah OPD di Kabupaten Kudus sebanyak 43 OPD yang terdiri dari 12 dinas, 2 sekretariat, Inspektorat, RSUD, 3 badan, 6 kantor, 9 kecamatan dan 9 kelurahan. Dari 43 OPD tersebut terdapat 551 pejabat struktural yang terdiri dari kepala OPD, sekretaris OPD, kepala sub bagian/kepala sub bidang, dan kepala seksi dan staff keuangan yang memiliki peran dalam proses penyusunan anggaran.Teknik pengambilan sampel menggunakan rumus Slovin yang menghasilkan 85 responden (Sanusi, 2017). 


\section{Prosedur}

Data yang digunakan dalam penelitian ini dikumpulkan melalui sumber data primer dan sumber data sekunder. Sumber data primer diperoleh melalui kuesioner yang dibagikan kepada pegawai OPD Kabupaten Kudus yang masuk dalam kriteria sampel. Sedangkan data sekunder diperoleh melalui literature buku untuk mendukung penelitian ini.

\section{Data, Instrumen, dan Teknik}

\section{Pengumpulan Data}

Pegawai OPD Kabupaten Kudus yang termasuk dalam sampel penelitian ini akan diberi kuesioner untuk mengisi pernyataan yang sudah disusun dengan cara menuliskan checklist pada masingmasing pernyataan. Kuesioner yang disusun ini terdiri dari beberapa instrumen penelitian. Instrumen yang digunakan dalam penelitian ini mengacu dengan penelitian terdahulu dari masingmasing variabel. Berikut ini instrumen yang digunakan dalam penelitian ini :

a). Kinerja Manajerial

Kinerja manajerial adalah prestasi yang diraih oleh seorang pegawai OPD yang terkait dengan penyusunan anggaran meliputi : kepala OPD, kepala bagian, kepala sub bagian, kepala seksi, staff yang terkait dengan penyusunan anggaran dalam menjalankan tugasnya sesuai dengan tanggung jawab yang semestinya dilakukan (Ermawati, 2017). Kinerja manajerial menggunakan instrumen penelitian yang telah dilakukan oleh Ermawati (2017) dengan menggunakan delapan item pernyataan.

b). Partisipasi Anggaran

Partisipasi anggaran adalah proses dalam menyusun anggaran dimana semua level pegawai mulai dari staff, kabid, kabag, kepala OPD dalam sebuah instansi ikut serta dalam menentukan berapa jumlah anggaran yang dibutuhkan dalam instansi tersebut (Ermawati, 2017). Indikator yang digunakan dalam penelitian ini mengacu pada penelitian yang pernah dilakukan oleh Ermawati (2017) dengan menggunakan enam indikator pernyataan.

\section{c). Sistem Perencanaan Anggaran}

Sistem perencanaan anggaran adalah sistem perencanaan dalam menyusun anggaran dimana sebuah organisasi ini harus memiliki target kinerja dan hasil untuk efisiensi pelaksanaan program (Hidayat, 2015). Indikator yang digunakan dalam penelitian ini mengacu pada penelitian yang telah dilakukan oleh Hamid (2011) dengan menggunakan Sembilan item pernyataan. 
d). Skedul Penyusunan Anggaran

Skedul penyusunan anggaran adalah jadwal yang dibuat oleh instansi terkait penyusunan anggaran, dimana jadwal tersebut apakah sesuai dengan pelaksanaan dalam penyusunan anggaran (Hidayat, 2014). Indikator penelitian ini mengacu pada penelitian yang telah dilakukan oleh Syafrial (2009) dengan menggunakan enam item pernyataan.

e). Kejelasan Sasaran Anggaran

Kejelasan sasaran anggaran adalah kejelasan dari tujuan anggaran yang telah ditetapkan di awal penyusunan terkait tentang pengelolaan keuangan sehingga anggaran dapat dengan mudah dipertanggungjawabkan oleh yang menjalankan (Fitriana et al., 2018). Indikator dalam variabel ini menggunakan item pernyataan dari Hidayat (2014) dengan menggunakan 3 indikator penentuan jumlah anggaran, program kegiatan menentukan skala prioritas dan mudah dimengerti.

f). Kualitas Sumber Daya Manusia

Menurut Juita (2013) kualitas sumber daya manusia adalah seberapa besar seorang pegawai mampu untuk menjalankan tugas, fungsi dan tanggung jawab atas pekerjaan yang di kerjakan dalam sebuah perusahaan. Indikator kualitas sumber daya manusia ini mengacu pada penelitian yang telah dilakukan oleh Juita (2013) yang dilihat dari pendidikan, pengalaman dan pelatihan. Indikator yang digunakan menggunakan 9 item pernyataan.

\section{Teknik Analisis Data}

Teknik analisis data yang digunakan dalam penelitian ini terdiri dari:

a. Uji Instrumen: uji instrumen ini digunakan untuk 1). Menilai sah atau tidaknya kuesioner yang digunakan dengan menggunakan uji validitas. Uji validitas ini dikatakan valid jika nilai signifikansinya $<0,05$ (Ghozali, 2011). 2). Menilai apakah instrumen yang digunakan menggunakan item pernyataan yang konsisten dari satu pernyataan ke pernyataan yang lain (Ghozali, 2011). Kuesioner yang digunakan dikatakan reliabel jika nilai cronbach alpha > 0,60 (Ghozali, 2011).

b. Uji Asumsi Klasik

Uji asumsi klasik penting dilakukan sebelum menggunakan uji hipotesis yaitu regresi berganda. Berikut ini uji asumsi klasik yang harus dipenuhi dalam penelitian ini sebagai berikut :

1). Uji Normalitas

Uji normalitas digunakan untuk menguji data yang digunakan dalam 
penelitian ini harus terdistribusi normal. Uji normalitas ini terpenuhi menggunakan uji Kolmogorof Smirnov. Data dikatakan normal jika hasil dari nilai signifikansi nya > 0,05 (Ghozali, 2011).

2). Uji Multikolonieritas

Uji multikolonieritas digunakan untuk menguji apakah ada hubungan antar variabel independen yang sedang diteliti. Penelitian yang bagus harus terbebas dari multikolonieritas. Bebas multikolonieritas jika nilai VIF $<10$ dan nilai tolerance $<1$.

3). Uji heteroskedastisitas

Uji heteroskedastisitas digunakan untuk menguji apakah data yang digunakan dalam penelitian ini menyebar secara acak ataukah mengumpul pada satu titik. Penelitian yang bagus harus terbebas dari heteroskedastisitas. A

c. Uji Hipotesis

Uji hipotesis yang digunakan dalam penelitian ini menggunakan metode Moderate Regression Analysis (MRA). Metode MRA digunakan untuk menguji hipotesis yang menggunakan variabel moderating.

MRA merupakan pengujian hipotesis dengan menggunakan perkalian dengan variabel independen 1 dengan variabel independen yang lainnya.
Berikut ini persamaan yang digunakan untuk menguji hipotesis : $\mathrm{Y}=\mathrm{a}+\mathrm{b} 1 \mathrm{X} 1+\mathrm{b} 2 \mathrm{X} 2+\mathrm{b} 3 \mathrm{X} 3+\mathrm{b} 4 \mathrm{X} 4+$ $b 5 X 1 Z+b 6 X 2 Z+b 7 X 3 Z+b 8 X 4 Z+e$

Keterangan :

$\mathrm{Y}=$ Kinerja Manajerial

$\mathrm{a}=$ Intercept

b1 =Koefisien Regresi Partisipasi Anggaran

b2 =Koefisien Regresi Sistem Perencanaan Anggaran

b3 =Koefisien Regresi Skedul Penyusunan Anggaran

b4 =Koefisien Regresi Kejelasan Sasaran Anggaran

b5, b6, b7, b8 = Koefisien Regresi Variabel Moderasi Kualitas Sumber Daya Manusia

$\mathrm{X} 1=$ Partisipasi Anggaran

$\mathrm{X} 2=$ Sistem Perencanaan Anggaran

X3 = Skedul Penyusunan Anggaran

X4 = Kejelasan Sasaran Anggaran

$\mathrm{Z}=$ Kualitas Sumber Daya Manusia

e $\quad=$ Variabel Pengganggu

Pengambilan keputusan uji ini dengan melihat besarnya nilai signifikansi. Jika nilai signifikansi $<0,05$, maka hipotesis diterima. Begitu juga sebaliknya jika nilai signifikansi > 0,05 maka hipotesis ditolak.

\section{HASIL PENELITIAN DAN \\ PEMBAHASAN}

\section{Hasil}

a. Hasil Uji Instrumen 


\section{1). Uji Reliabilitas}

Hasil uji instrumen ini dapat dilihat dengan menggunakan uji reliabiltas. Uji reliabilitas ini digunakan untuk mengetahui apakah intrumen yang digunakan dalam penelitian ini konsisten dari satu pernyataan ke pernyataan yang lainnya. Berikut ini disajikan hasil pengujian Reliabilitas

Tabel 1 Hasil Pengujian Reliabilitas

\begin{tabular}{|c|c|c|c|}
\hline No & Variabel & $\begin{array}{c}\text { Cronbach } \\
\text { Alpha }\end{array}$ & Ket. \\
\hline 1 & $\begin{array}{l}\text { Partisipasi } \\
\text { Penyusunan } \\
\text { Anggaran }\end{array}$ & 0,792 & Reliabel \\
\hline 2 & $\begin{array}{l}\text { Sistem } \\
\text { Perencanaan } \\
\text { Anggaran }\end{array}$ & 0,830 & Reliabel \\
\hline 3 & $\begin{array}{l}\text { Skedul } \\
\text { Penyusunan } \\
\text { Anggaran }\end{array}$ & 0,657 & Reliabel \\
\hline 4 & $\begin{array}{l}\text { Kejelasan } \\
\text { Anggaran }\end{array}$ & 0,797 & Reliabel \\
\hline 5 & $\begin{array}{l}\text { Kualitas } \\
\text { Sumber } \\
\text { Daya } \\
\text { Manusia }\end{array}$ & 0,828 & Reliabel \\
\hline 6 & $\begin{array}{l}\text { Kinerja } \\
\text { Manajerial }\end{array}$ & 0,873 & Reliabel \\
\hline
\end{tabular}

Berdasarkan tabel di atas menunjukkan bahwa nilai Cronbach Alpha melebihi nilai 0,60. Hal ini menunjukkan bahwa instrumen penelitian ini memenuhi reliabilitas.

\section{2). Uji Validitas}

Uji instrumen yang ke dua adalah uji validitas. Uji ini digunakan untuk menguji sah atau tidaknya pernyataan penelitian yang telah di sebarkan kepada responden. Berikut ini hasil pengujian validitas :

Tabel 2 Hasil Pengujian Validitas

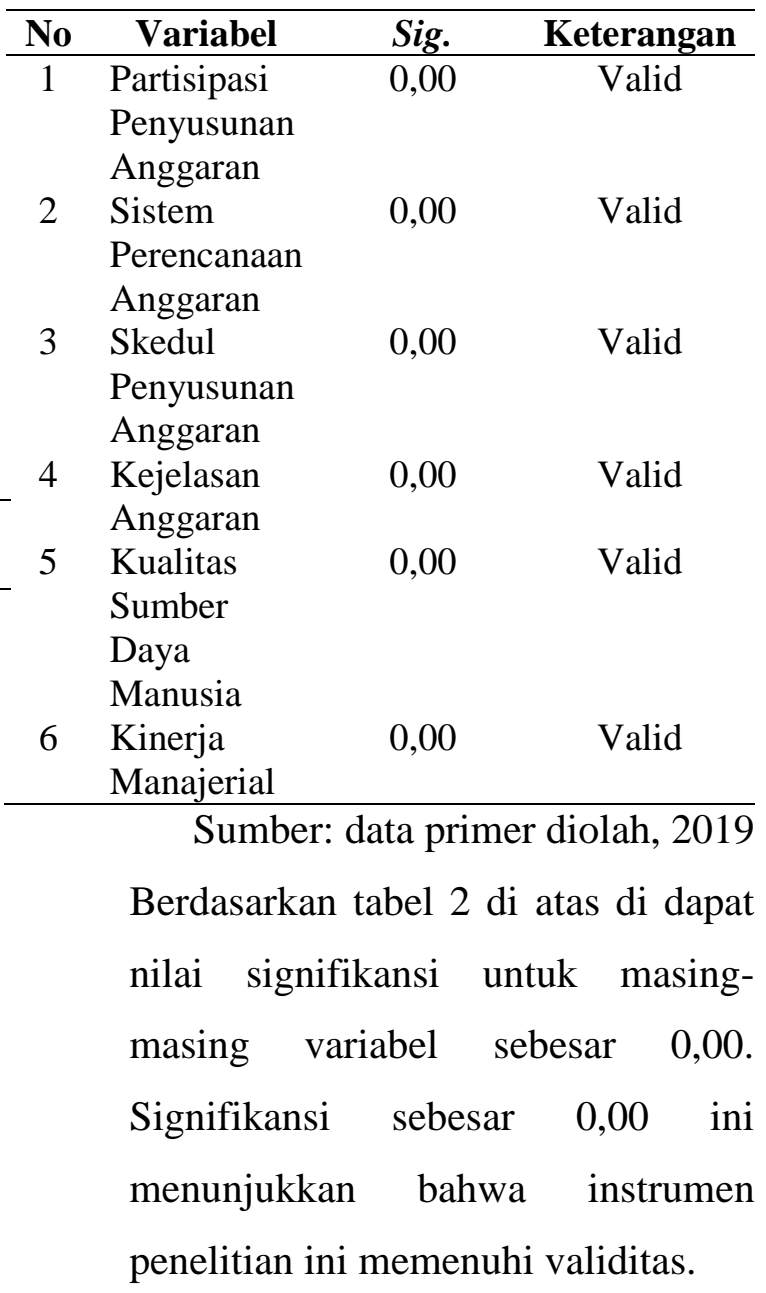

\section{b. Hasil Uji Asumsi Klasik}

\section{1). Hasil Uji Normalitas}

Uji normalitas digunakan untuk menentukan apakah model regresi yang digunakan memiliki distribusi normal atau tidak. Pengujian normalitas ini menggunakan uji Kolmogorof Smirnov. Berikut ini hasil pengujian normalitas: 
mempengaruhi variabel dependen. Adjusted $R$ Square juga digunakan untuk mengevaluasi model regresi yang baik. Berikut ini disajikan tabulasi untuk koefisien determinasi dan Adjusted $R$ Square :

Tabel 6 Koefisien Determinasi

\begin{tabular}{|c|c|c|c|}
\hline & & & Adjusted R \\
\hline Model & $R$ & $R$ Square & Square \\
\hline 1 & $0,531^{a}$ & 0,282 & 0,196 \\
\hline
\end{tabular}

Sumber : data primer diolah, 2019

Berdasarkan tabel 6 di atas menunjukkan nilai adjusted $r$ square sebesar 0,196. Adjusted $R$ Square sebesar 0,196 ini menunjukkan bahwa sebesar 19,6\% variabel partisipasi penyusunan anggaran, sistem perencanaan anggaran, skedul penyusunan anggaran, kejelasan anggaran, kualitas sumber daya manusia mampu mempengaruhi kinerja manajerial. Sedangkan sisanya sebesar $80,4 \%$ variabel kinerja manajerial dipengaruhi oleh variabel lain yang tidak diteliti dalam penelitian ini.

\section{2). Hasil Uji Statistik F}

Uji statistik F digunakan untuk menilai apakah semua variabel independen yang digunakan dalam penelitian ini yang terdiri dari partisipasi penyusunan anggaran, sistem perencanaan anggaran, skedul penyusunan anggaran, kejelasan anggaran, kualitas sumber daya manusia dapat secara bersamasama mampu menjelaskan variabel dependen yaitu kinerja manajerial. Syarat pengujian ini

jika nilai signifikansi menghasilkan nilai di bawah 0,05 dapat dikatakan variabel independen secara bersama-sama mampu menjelaskan variabel dependen.

Tabel 7 Hasil Uji F

\begin{tabular}{lll}
\hline Model & $\boldsymbol{F}$ & Sig. \\
\hline Regression & 3,280 & 0,002 \\
\hline \multicolumn{2}{c}{ Sumber : data primer diolah, 2019 }
\end{tabular}

Berdasarkan tabel 7 di atas menunjukkan nilai signifikansi 0,002. Signifikansi 0,002 menandakan kurang dari 0,05, yang berarti bahwa partisipasi penyusunan anggaran, sistem perencanaan anggaran, skedul penyusunan anggaran, kejelasan anggaran, kualitas sumber daya manusia secara bersama-sama mampu menjelaskan variabel dependen.

3). Hasil Uji Moderate Regression Analysis (MRA)

Pengujian hipotesis menggunakan Uji Moderate Regression Analysis (MRA). Berikut ini disajikan tabulasi hasil pengujian hipotesis:

Tabel 8 Hasil Uji Moderate Regression Analysis (MRA)

\begin{tabular}{ccl}
\hline Hipotesis & Sig & \multicolumn{1}{c}{ Keterangan } \\
\hline H1 & 0,811 & Hipotesis ditolak \\
H2 & 0,555 & Hipotesis ditolak \\
H3 & 0,227 & Hipotesis ditolak \\
H4 & 0,044 & Hipotesis diterima \\
H5 & 0,524 & Hipotesis ditolak \\
H6 & 0,586 & Hipotesis ditolak \\
H7 & 0,228 & Hipotesis ditolak \\
H8 & 0,038 & Hipotesis diterima \\
\hline \multicolumn{3}{l}{ Sumber : data primer diolah, 2019 }
\end{tabular}




\section{Pembahasan}

\section{a. Partisipasi Penyusunan Anggaran Berpengaruh Positif Terhadap Kinerja Manajerial}

Hipotesis pertama dalam penelitian ini adalah partisipasi anggaran berpengaruh positif terhadap kinerja manajerial. Secara statistik, berdasarkan tabel 8di atas menunjukkan hipotesis pertama ditolak. Hal ini dikarenakan nilai signifikansinya lebih dari 0,05 yaitu sebesar 0,811. Hasil penelitian menunjukkan bahwa partisipasi anggaran tidak dapat berpengaruh terhadap kinerja manajerial.

Keikutsertaan pegawai OPD dari level atas yaitu kepala OPD sampai dengan level bawah yaitu staff OPD yang terkait dengan penyusunan anggaran tidak mampu mempengaruhi kinerja manajerial OPD tersebut. Keikutsertaan pegawai OPD dalam menyusun rencana kerja anggaran (RKA) hanya sebatas menjalankan pekerjaan nya saja sebagai suatu kewajiban. Selain itu pegawai OPD dalam menyusun anggaran sudah memiliki ketentuan sendiri dari pemerintah, sehingga anggaran yang dibuat tidak bisa fleksibel karena harus memenuhi peraturan dari pemerintah. Hal ini tidak sejalan dengan agensi teori dimana pejabat OPD seharusnya mampu menjadi agen yang menyusun anggaran sesuai dengan kondisi OPD yang semestinya, namun realitanya pejabat OPD tidak menyusun anggaran tidak maksimal sehingga kinerja manajerial kurang bagus.

Berdasarkan hasil penelitian menunjukkan sebanyak $44,7 \%$ atau 38 responden menduduki jabatan sebagai Kepala Sub Bagian/Kepala Sub Bidang dimana jabatan tersebut memiliki banyak tugas dalam OPD, sehingga tugasnya dalam menyusun anggaran dijalankan kurang maksimal. Kurang maksimal dalam menyusun anggaran ini menimbulkan kinerja OPD kurang maksimal juga

Hasil penelitian ini mendukung penelitian yang telah dilakukan oleh Ermawati (2017). Namun penelitian ini tidak mendukung penelitian yang telah dilakukan oleh Hidayat (2014), Gunawan (2017), Syafrial (2009), Oyewo \& Adyeye (2018).

\section{b. Sistem Perencanaan Anggaran Berpengaruh Positif Terhadap Kinerja Manajerial}

Hipotesis kedua dalam penelitian ini adalah sistem perencanaan anggaran berpengaruh positif terhadap kinerja manajerial. Berdasarkan tabel 8 di atas di dapatkan nilai signifikansi sebesar 0,555, dimana nilai signifikansinya lebih besar dari 0,05. Dapat disimpulkan bahwa sistem perencanaan anggaran tidak berpengaruh terhadap kinerja manajerial.

Sistem perencanaan anggaran merupakan sistem dalam penyusunan program atau kegiatan untuk OPD di masa 
yang akan datang yaitu satu tahun kemudian.

Dalam penelitian ini sistem perencanaan anggaran di OPD Kabupaten Kudus tidak direncanakan secara matang sehingga target organisasi tidak sesuai dengan kebutuhan organisasi. Jika perencanaan anggaran ini tidak dijalankan dengan matang akan menghasilkan kinerja OPD yang kurang bagus karena tidak sesuai dengan target organisasi. Berdasarkan hasil kuesioner di dapatkan bukti bahwa sistem perencanaan yang kurang matang menyebabkan banyaknya kegiatan yang tidak perlu dalam KUA -PPAS. Hal ini tidak sejalan dengan tugas pejabat OPD sebagai agen yang mampu merencanakan anggaran dengan baik. Hasil penelitian ini tidak mendukung penelitian yang telah dilakukan oleh Hidayat (2014).

\section{c. Skedul Penyusunan Anggaran Berpengaruh Positif Terhadap Kinerja Manajerial}

Hipotesis ketiga dalam penelitian ini adalah skedul penyusunan anggaran berpengaruh positif terhadap kinerja manajerial. Secara statistik di dapatkan nilai signifikansi sebesar 0,227, dimana nilai ini lebih dari 0,05 yang menunjukkan hipotesis ditolak. Dapat disimpulkan bahwa skedul penyusunan anggaran tidak berpengaruh terhadap kinerja manajerial.

Skedul penyusunan rencana kerja anggaran di OPD Kabupaten Kudus mengalami keterlambatan penetapan anggaran oleh DPRD dari jadwal yang telah ditetapkan. Hal ini dapat ditunjukkan dari besarnya nilai mean skedul penyusunan anggaran 10,235. Dimana nilai maksimumnya 20, yang artinya jauh dari ketepatan dalam penyusunan anggaran. Keterlambatan dalam pengesahan anggaran inilah yang menybabkan kinerja manajerial dari masing-masing OPD kurang maksimal. OPD akan bekerja kurang maksimal karena jadwal yang seharusnya dilaksanakannya program atau kegiatan OPD akan terganggu pelaksanaannya. Hasil penelitian tidak mendukung agensi teori, dimana Pemerintahan Kabupaten Kudus tidak mampu menjadi agen yang baik karena skedul penyusunan anggaran tidak sesuai dengan jadwal yang telah ditentukan. Hasil penelitian ini mendukung penelitian yang telah dilakukan oleh Syafrial (2009).

\section{d. Kejelasan Anggaran Berpengaruh Positif Terhadap Kinerja Manajerial}

Hipotesis keempat dalam penelitian ini adalah kejelasan anggaran berpengaruh positif terhadap kinerja manajerial. Berdasarkan tabel 8 di dapatkan nilai signifikansi sebesar 0,044, dimana 0,044 lebih kecil dari 0,05 . Hal ini menunjukkan hipotesis diterima. Dapat disimpulkan bahwa kejelasan anggaran berpengaruh positif terhadap kinerja manajerial. 
Kejelasan sasaran anggaran merupakan hal yang sangat penting bagi organisasi, yaitu dimana anggaran disusun tepat antara sasaran dengan program kegiatan yang akan dijalankan. Sasaran program kegiatan OPD Kabupaten Kudus masingmasing tidak terdapat pada sasaran program kegiatan OPD lainnya. Dengan kejelasan sasaran anggaran yang tepat inilah akan meningkatkan kinerja manajerial OPD tersebu. Hal ini menunjukkan bahwa dengan sasaran anggaran yang jelas, maka OPD akan bekerja secara maksimal untuk menjalankan kegiatan organisasinya. Hal ini sejalan dengan teori agensi dimana, agensi mampu mampu menjadi agen yang baik karena sasaran yang dibuat oleh OPD Kudus jelas sesuai dengan sasarannya.

Hasil penelitian ini mendukung penelitian yang telah dilakukan oleh Hidayat (2014), Gunawan (2017), Syafrial (2009), Putra (2013), Hidayat (2015). Namun penelitian ini tidak mendukung penelitian yang telah dilakukan oleh Fitriana et al.,( 2018).

\section{e. Kualitas Sumber Daya Manusia Memperkuat Pengaruh Partisipasi Penyusunan Anggaran Terhadap Kinerja Manajerial}

Hipotesis ke lima adalah kualitas sumber daya manusia memperkuat partisipasi anggaran terhadap kinerja manajerial. Berdasarkan tabel 8di atas menunjukkan bahwa nilai signifikansi sebesar 0,524. Nilai signifikansi pada hipotesis ke lima menunjukkan lebih besar dari 0,05 , hal ini menunjukkan bahwa hipotesis ke lima ditolak. Dapat diartikan bahwa kualitas sumber daya manusia tidak mampu memperkuat pengaruh partisipasi anggaran terhadap kinerja manajerial.

Kualitas sumber daya manusia seharusnya menjadi faktor penting dalam pengambilan keputusan, misalnya dalam penyusunan anggaran. Dalam penyusunan anggaran pada OPD Kabupaten Kudus ini melibatkan pegawai OPD level atas sampai level bawah, namun keikutsertaan pegawai OPD ini hanya sebatas menjalankan tugasnya saja sebagai pegawai, sehingga kinerja manajerial OPD kurang maksimal. Apalagi responden dalam penelitian merupakan pegawai yang memiliki intensitas pekerjaannya banyak, sehingga dalam menyusun anggaran hanya sebatas menjalankan kewajiban saja. Dengan kata lain tinggi rendahnya pengetahuan dari masing-masing OPD dalam menyusun anggaran ini tidak mampu memperkuat partisipasi anggaran terhadap kinerja manajerial.

Hasil penelitian menolak dari agensi teori, dimana kualitas sumber daya manusia OPD kudus tidak mampu memoderasi partisipasi anggaran terhadap kinerja manajerial. Hal ini terjadi karena memang 
partisipasi pegawai OPD dalam menyusun anggaran hanya sebatas kewajibannya saja tanpa memperhatikan kemajuan OPD. Hasil penelitian ini sejalan dengan penelitian dari Hidayat (2015).

\section{f. Kualitas Sumber Daya Manusia Memperkuat Pengaruh Sistem Perencanaan Anggaran Terhadap} Kinerja Manajerial

Hipotesis yang ke 6 adalah kualitas sumber daya manusia memperkuat pengaruh sistem perencanaan anggaran terhadap kinerja manajerial. Berdasarkan tabel 8, menunjukkan nilai signifikansi sebesar 0,586. Dimana signifikansi $0,586>0,05$ yang berarti bahwa hipotesis ditolak. Dengan kata lain, kualitas sumber daya manusia tidak mampu memoderasi pengaruh sistem perencanaan anggaran terhadap kinerja manajerial. Tinggi rendahnya kualitas sumber daya manusia masing-masing OPD Kabupaten Kudus tidak dapat memperkuat pengaruh sistem perencanaan anggaran terhadap kinerja manajerial OPD Kabupaten Kudus.

Sumber daya manusia OPD Kabupaten Kudus ini dapat dilihat dari pengetahuan yang dimiliki pegawai OPD dalam memahami penyusunan anggaran. Sesuai dengan hasil pengujian hipotesis kedua di atas bahwa anggaran yang disusun oleh masing-masing OPD kurang direncanakan secara matang, walaupun sumber daya manusia nya berkualitas, tetapi anggaran disusun tidak dengan matang akan menghasilkan prestasi kerja OPD yang kurang maksimal. Hal ini lah yang menyebabkan tinggi rendahnya kualitas sumber daya manusia ini tidak mampu memperkuat pengaruh sistem perencanaan anggaran terhadap kinerja manajerial OPD.

Hasil penelitian tidak sejalan dengan agensi teori, dimana kualitas sumber daya manusia pejabat OPD tidak akan mempengaruhi kinerja manajerial karena perencanaan anggaran Pemerintah Kudus tidak dilaksanakan dengan baik. Hal ini sejalan dengan hasil penelitian yang telah dilakukan oleh Hidayat (2015).

\section{g. Kualitas Sumber Daya Manusia Memperkuat Pengaruh Skedul Penyusunan Anggaran Terhadap Kinerja Manajerial}

Hipotesis ketujuh dalam penelitian ini adalah kualitas sumber daya manusia memperkuat skedul penyusunan anggaran terhadap kinerja manajerial. Berdasarkan tabel 8 di atas menunjukkan nilai signifikansi sebesar 0,228. Nilai signifikansi ini lebih besar dari 0,05, yang menunjukkan bahwa hipotesis ditolak. Dengan kata lain kualitas sumber saya manusia tidak mampu memperkuat pengaruh skedul penyusunan anggaran terhadap kinerja manajerial.

Dalam pelaksanaan penyusunan anggaran di OPD Kabupaten Kudus tidak 
dijalankan sesuai dengan jadwal yang telah ditetapkan. Dengan kata lain tidak terdapat kesesuaian waktu dalam penyusunan anggaran. Dengan tidak tepat waktu nya dalam penyusunan anggaran, walaupun di dukung dengan sumber daya manusia yang berkualitas ternyata tidak mampu menghasilkan kinerja manajerial yang baik. Karena waktu yang telah ditetapkan molor, sehingga program kerja OPD tidak dapat dijalankan dengan baik, sehingga kinerja OPD kurang maksimal.

Hasil penelitian tidak sejalan dengan penelitian yang telah dilakukan oleh Hidayat (2015). Secara teori, hasil penelitian ini tidak mendukung agensi teori karena agen dengan kualitas sumber daya manusia yang baguspun tidak mampu memperkuat skedul penyusunan anggaran terhadap kinerja manajerial. Hal ini disebabkan karena skedul penyusunan anggaran tidak tepat waktu.

h. Kualitas Sumber Daya Manusia Memperkuat Pengaruh Kejelasan

Anggaran Terhadap Kinerja
Manajerial

Hipotesis kedelapan dalam penelitian ini adalah kualitas sumber daya manusia memperkuat pengaruh kejelasan anggaran terhadap kinerja manajerial. Berdasarkan tabel 8 di atas nilai signifikansi sebesar 0,038. Hal ini menunjukkan hipotesis diterima karena nilai signifikansi kurang dari 0,05. Dapat disimpulkan bahwa kualitas sumber daya manusia mampu memperkuat pengaruh kejelasan anggaran terhadap kinerja manajerial.

Anggaran yang disusun memiliki tujuan yang jelas dan sesuai dengan sasaran jika di dukung dengan kualitas sumber daya manusia yang bagus akan menghasilkan kinerja yang bagus bagi OPD. Anggaran yang telah jelas tujuan penggunaannya kemudian di laksanakan oleh sumber daya manusia yang handal akan membuat hasil kerja OPD semakin bagus. Hal ini dikarenakan anggaran yang disusun oleh Pemerintah daerah Kabupaten Kudus tepat sesuai dengan sasaran dan kebutuhan. Anggaran yang telah jelas sasarannya akan dengan mudah dilaksanakan oleh OPD dalam mencapai target yang telah direncanakan sehingga tercipta peningkatan kinerja OPD Kabupaten Kudus.

Hasil penelitian ini sejalan dengan agensi teori, karena agen mampu mempertanggungjawabkan tugasnya sebagai abdi masyarakat. Dengan kualitas sumber daya manusia yang memadhi maka akan memperkuat pengaruh kejelasan anggaran terhadap kinerja manajerial. Dengan anggaran yang jelas dan didukung sumber daya manusia yang handal akan meningkatkan kinerja manajerial. Hasil penelitian ini tidak sejalan dengan hasil penelitian dari Hidayat (2014). 


\section{SIMPULAN DAN SARAN}

\section{Simpulan}

Kesimpulan yang dapat ditarik dari hasil penelitian ini adalah:

1. Partisipasi penyusunan anggaran yang diukur dengan enam indikator tidak berpengaruh terhadap kinerja manajerial

2. Sistem perencanaan anggaran yang diukur dengan sembilan indikator tidak berpengaruh terhadap kinerja manajerial

3. Skedul penyusunan anggaran diukur dengan enam indikator tidak berpengaruh terhadap kinerja manajerial

4. Kejelasan anggaran yang diukur dengan menggunakan tiga indikator yaitu penentuan jumlah anggaran, program kegiatan menentukan skala prioritas dan mudah dimengerti berpengaruh positif terhadap kinerja manajerial

5. Kualitas sumber daya manusia tidak mampu memperkuat pengaruh sistem perencanaan anggaran terhadap kinerja manajerial

6. Kualitas sumber daya manusia tidak mampu memperkuat pengaruh partisipasi penyusunan anggaran terhadap kinerja manajerial

7. Kualitas sumber daya manusia tidak mampu memperkuat pengaruh skedul penyusunan anggaran terhadap kinerja manajerial
8. Kualitas sumber daya manusia mampu memperkuat pengaruh kejelasan anggaran terhadap kinerja manajerial

\section{Saran}

Saran yang dapat di berikan oleh peneliti untuk penelitian selanjutnya diantaranya:

1. Populasi penelitian yang digunakan lebih diperluas lagi, dengan menambah populasi yaitu Organisasi Perangkat Daerah (OPD) se Karesidenan Pati yang meliputi Kabupaten Pati, Kabupaten Kudus, Kabupaten Rembang, Kabupaten Blora, Kabupaten Jepara. Hal ini supaya lebih dapat digeneralisasi.

2. Metode Analisis MRA yang digunakan pengujian hipotesis menghasilkan $\mathrm{H} 1$, H2, H3, H5, H6, H7 ditolak. Sedangkan H4 dan H8 diterima. Disarankan untuk mengganti teknik analisis data menggunakan uji Partial Least Square (PLS) dengan harapan akan memberikan hasil pengujian yang lebih akurat lagi (Ermawati, 2017).

3. Penelitian selanjutnya dapat menambah variabel independen lainnya misalnya motivasi kerja hal ini sesuai dengan keterbatasan penelitian ini dimana nilai adjusted $R$ Square hanya menunjukkan $19,6 \%$ variabel independen secara bersama-sama yang mampu mempengaruhi kinerja manajerial, yang artinya masih $80,4 \%$ variabel 
independen lainnya yang tidak diteliti yang mampu mempengaruhi kinerja manajerial (Ermawati, 2017).

\section{DAFTAR PUSTAKA}

Bergman, M., \& Lane, J.-E. (1990). Public Policy in A Principal-Agent Framework. Journal of Theoretical Politics, 2(3), 339-352.

Dewi, N. L. P. L., Dwirandra, A. A. N. B., Wirakusuma, \& Made Gede Wirakusuma. (2017). Kemampuan Komitmen Organisasi Memoderasi Pengaruh Perencanaan Anggaran Dan Kompetensi Sdm Pada Penyerapan Anggaran Pemerintah Kabupaten Tabanan. E-Jurnal Ekonomi Dan Bisnis Universitas Udayana, 4, 1609-1638.

Ermawati, N. (2017). Pengaruh Partisipasi Anggaran Terhadap Kinerja Manajerial Dengan Motivasi Kerja Sebagai Variabel Pemoderasi (Studi Kasus SKPD Kabupaten Pati). Jurnal Akuntansi Indonesia, 6(2), 141-156.

Fauziah, Junaidi, H., \& Yuliusman. (2017). Pengaruh Ketepatan Skedul Anggaran Dan Karakteristik Tujuan Anggaran Terhadap Kinerja Manajerial Satuan Kerja Perangkat Daerah Kabupaten Batanghari Provinsi Jambi. Jurnal Akuntansi \& Keuangan Magister Ilmu Akuntansi Universitas Jambi, 2(3), 7386.

Fitriana, R. D., Hidayati, N., \& Mawardi, M. C. (2018). Kejelasan Sasaran Anggaran,Pengendalian Akuntansi, Dan Sistem Pelaporan Terhadap Akuntabilitas Kinerja Instansi Pemerintah Daerah. E-JRA Fakultas Ekonomi Dan Bisnis Universitas Islam Malang, 07(02), 91-103.

Ghozali, I. (2011). Aplikasi Analisis Multivariate dengan Program IBM SPSS 21 (7th ed.). Semarang: Badan
Penerbit Universitas Diponegoro.

Gunawan, S. I. (2017). Analisis Faktor Faktor Yang Mempengaruhi Kinerja Manajerial Satuan Kerja Perangkat Daerah Di Pemerintah Provinsi Sumatera Utara Dengan Pengendalian Internal Sebagai Variabel Moderating. Tesis. Fakultas Ekonomi \& Bisnis Universitas Sumatera Utara Medan.

Halim, A., \& Kusufi, M. S. (2014). Teori, Konsep, dan Aplikasi Akuntansi Sektor Publik: dari Anggaran hingga Laporan Keuangan, dari Pemerintah hingga Tempat Ibadah. Jakarta: Salemba Empat.

Hamid, R. (2011). Pengaruh Sistem Perencanaan Anggaran, Sistem Informasi Keuangan Daerah Dan Sistem Pengelolaan Keuangan Daerah di Era Otonomi Daerah Terhadap Kemampuan Daya Serap Anggaran di Pemerintahan Kota DKI Jakarta. Tesis.Program Magister Akuntansi Universitas Trisakti.

Haykal, M. (2007). Analisis Peran dan Fungsi SKPD dalam Pengelolaan Keuangan Daerah serta Pengaruhnya terhadap Kinerja (Studi Kasus pada Pemkab Aceh Timur. Tesis. Universitas Sumatera Utara.

Hidayat, T. (2014). Analisis Faktor-Faktor Yang Mempengaruhi Kinerja Manajerial. Akuntabilitas, 7(1), 56-68.

Hidayat, T. (2015). Pengaruh Kejelasan Sasaran Anggaran, Struktur Desentralisasi Dan Locus of Control Terhadap Kinerja Manajerial. Akuntabilitas, 8(2), 148-161.

Juita, S. D. (2013). Pengaruh Kualitas Sumber Daya Manusia, Komitmen Organisasi Dan Komunikasi Organisasi Terhadap Kinerja Satuan Kerja Perangkat Daerah (SKPD) (Studi Empiris pada SKPD Pemerintah Kota 
Padang) Oleh. Jurnal Akuntansi Universitas Negeri Padang, 1(3), 1-17.

Matondang, N. I. D., Basri, H., \& Arfan, M. (2015). Pengaruh Sinkronisasi Perencanaan Dan Penganggaran, Partisipasi Anggaran Dan Kejelasan Sasaran Anggaran Terhadap Kinerja SKPD Pada Pemerintah Kabupaten Aceh Utara. Jurnal Magister Akuntansi Pascasarjana Universitas Syiah Kuala 10, 4(4), 36-45. https://doi.org/10.2514/1.40133

N.A. (2018). Target APBD Kudus 2018 Anjlok.

Https://Jateng.Antaranews.Com/Detail/ Target-Apbd-2018-Anjlok-Dprd-

Kudus-Prihatin.Html.

Oyewo, B., \& Adyeye, G. (2018). BUDGETARY PARTICIPATION AND MANAGERIAL PERFORMANCE IN PUBLIC SECTOR ORGANISATIONS: A STUDY FROM NIGERIA. ICCS Economic Series, 5(1), 86-96.

Putra, D. (2013). Pengaruh akuntabilitas publik dan kejelasan sasaran anggaran terhadap kinerja manajerial satuan kerja perangkat daerah (Studi empiris pada satuan kerja perangkat daerah kota Padang). Jurnal Akuntansi, 1(1), 1-23.

Sanusi, A. (2017). Metode Penelitian Bisnis. Jakarta : Salemba Empat.

Sugiyono. (2012). Metode Penelitian Kuantitatif Kualitatif dan $R \& D$. Bandung: Alfabeta.

Syafrial. (2009). Pengaruh Ketepatan Skedul Penyusunan Anggaran, Kejelasan Sasaran Anggaran Dan Partisipasi Penyusunan Anggaran Terhadap Kinerja Manajerial SKPD Pada Pemerintah Kabupaten Sarolangun. Tesis. Sekolah Pascasarjana Universitas Sumatera Utara Medan.
Zein, M., Basri, Y., \& Supriono, S. (2016). Pengaruh Partisipasi Penyusunan Anggaran Dan Kejelasan Sasaran Anggaran Terhadap Kinerja Aparat Pemerintah Daerah Kabupaten Siak Dengan Komitmen Organisasi Sebagai Variabel Moderating (Studi Empiris Pada Satuan Kerja Perangkat Daerah Kabupaten Siak). Jurnal Online Mahasiswa Fakultas Ekonomi Universitas Riau, 3(1), 1550-1564. 